\title{
Kestabilan Model Epidemi Seir dengan Matriks Hurwitz
}

\section{Stability of a SEIR Epidemic Model with Hurwitz Matrices}

\author{
Roni Tri Putra ${ }^{1)}$, Sukatik $^{1)} \&$ Sri Nita ${ }^{2)}$ \\ ${ }^{1)}$ Jurusan Teknik Sipil, Politeknik Negeri Padang, Kampus Unand Limau Manis Padang, 25163. \\ Telp 0751-72590 Fax 0752-72576 Email: putra_tryronny@yahoo.co.id \\ dan atik_wiryosentono@yahoo.co.id \\ ${ }^{2)}$ Jurusan Teknik Elektro, Politeknik Negeri Padang, Kampus Unand Limau Manis Padang, 25163. \\ Telp 0751-72590 Fax 0752-72576 Email: srinita0610@ gmail.com
}

\begin{abstract}
In this paper, it will be studied local stability of equilibrium points of a SEIR epidemic model with infectious force in latent, infected and immune period. From the model it will be found investigated the existence and its stability of points its equilibrium by Hurwitz matrices. The local stability of equilibrium points is depending on the value of the basic reproduction number $\left(R_{0}\right)$. If $R_{0}<1$ the disease free equilibrium is local asymptotically stable.
\end{abstract}

Keyword : stability, equilibrium points, Hurwitz matrices

\section{PENDAHULUAN}

Penerapan model matematika dan teknik matematika untuk mendalami masalah biosciences dipelajari dalam mathematical biosciences. Salah satu cabang mathematical biosciences adalah mathematical epidemiology, yang mempelajari tentang penyebaran dan pengendalian penyakit.

Epidemik merupakan suatu keadaan dimana berjangkitnya suatu penyakit menular dalam populasi pada suatu tempat yang melebihi perkiraan kejadian yang normal dalam periode yang singkat. Bila penyakit tersebut selalu terdapat dalam suatu tempat begitupun dengan faktor penyebabnya maka dikatakan endemik.

Ada berbagai model matematika epidemi yang dikenal berdasarkan sifat atau ciri-ciri penyakitnya. Misalnya $S, E_{g} I$

dan $R$ berturut-turut menunjukkan Susceptible (kelas populasi yang rentan), Exposed (kelas populasi yang laten), Infectious (kelas populasi yang terinfeksi) dan Recovered (kelas populasi yang sembuh).

Dengan berbagai asumsi, dikenal berbagai model epidemi, diantaranya SIR,
SIRS, SEIR, SEIRS dan SEIS. Dalam model SIR, individu yang sembuh mempunyai kekebalan sehingga tidak lagi menjadi rentan, sedangkan untuk model SIRS individu yang sudah sembuh tidak memiliki kekebalan terhadap penyakit tersebut sehingga dapat menjadi rentan lagi.

Berbagai macam penyakit epidemik seperti campak (measles), tubercolosis, malaria dan Human Immunodeficiency Virus (HIV) mempunyai periode laten. Periode laten adalah selang waktu dimana suatu individu terinfeksi sampai munculnya penyakit. Dalam model SEIR, SEIRS dan SEIS individu yang rentan melalui masa laten setelah terinfeksi sebelum menjadi terjangkit.

Dalam tulisan ini hanya akan dibahas model SEIR. Untuk menganalisa kestabilan titik ekuilibrium pada model matematika epidemi, dilakukan dengan menganalisa kestabilan matriks, kriteria Routh-Hurwitz dan kemudian mengaplikasikannya dalam model epidemi SEIR.

Kriteria kestabilan Routh-Hurwitz adalah suatu metode yang digunakan untuk menunjukkan kestabilan sistem dengan memperhatikan koefisien dari persamaan karakteristik tanpa menghitung akar-akar 
secara langsung. Jika persamaan polinom adalah persamaan karakteristik, maka metode ini dapat digunakan untuk menentukan kestabilan dari suatu sistem. Kriteria Routh-Hurwitz tidak dapat menjelaskan bagaimana menstabilkan sistem tak stabil, tetapi dapat digunakan untuk menentukan batas penguatan suatu sistem agar masih stabil.

Sejalan dengan masalah yang akan dibahas, penelitian ini mempunyai tujuan sebagai berikut :

1. Membentuk model matematika epidemi SEIR pada populasi manusia

2. Menentukan titik-titik ekuilibrium model tersebut

3. Menyelidiki kestabilan titik-titik ekuilibrium model tersebut

4. Mengaplikasikan kriteria kestabilan matriks Hurwitz pada model epidemi SEIR.

Hasil penelitian ini diharapkan dapat :

1. Secara umum diharapkan dapat memberikan manfaat dan sumbangan terhadap ilmu pengetahuan, serta untuk menambah wawasan khususnya dalam bidang matematika terapan.

2. Secara khusus diharapkan dapat memberikan gambaran tentang model epidemi SEIR dengan kemampuan infeksi pada kelas laten, infeksi dan sembuh.

Kermack dan McKendrick (1927) telah memperkenalkan model epidemi. Dalam penelitian ini dipertimbangkan 4 kelas populasi yaitu $S$ (rentan), $E$ (laten), $I$ (infeksi) dan $R$ (sembuh). Anderson (1979) mempertimbangkan masalah ini dalam suatu tikus-tikus percobaan. Pearl dan Reed (1920) memperkenalkan model pertumbuhan logistik. Perko (1991) menjelaskan pengertian titik ekuilibrium pada sistem persamaan diferensial dan menjelaskan definisi nilai dan vektor eigen. Arrowsmith (1992) menjelaskan transformasi dengan matriks Jordan dan sistem persamaan diferensial linear dengan matriks berukuran $2 \times 2$.

Finizio (1998) menjelaskan pengertian macam-macam potret fase, selanjutnya Kocak (1991) menjelaskan matriks Jacobian suatu fungsi dari sistem non linear. Perko (1991) juga menjelaskan tentang linearisasi sistem non linear. Pada bukunya, Olsder (1994) memberikan penjelasan tentang kestabilan titik ekuilibrium ditinjau dari nilai eigen matriks Jacobian. Pease (1965) membahas tentang kriteria Routh- Hurwitz.

\section{METODOLOGI}

Metode penelitian dalam tulisan ini adalah dengan mempelajari jurnal-jurnal dan buku-buku yang berhubungan dengan penyakit epidemi, khususnya model SEIR. Oleh karenanya materi yang diteliti sebagian besar bersumber dari hasil karya ilmiah para pakar matematika dalam bentuk buku. Prosedur penelitian diawali dengan pemisalan, menentukan asumsi dan mendefinisikan parameter yang digunakan pada model. Setelah itu, dibuat diagram transfer model epidemi SEIR dan berdasarkan diagram transfer tersebut dituliskan model matematika epidemi SEIR.

Selanjutnya, menentukan titik-titik ekuilibrium model tersebut dengan menggunakan definisi titik ekuilibrium suatu sistem persamaan diferensial. Langkah selanjutnya menyelidiki sifat kestabilan lokal titik-titik ekuilibrium model tersebut. Untuk menyelidiki kestabilan lokal dilakukan linearisasi pada sistem dengan menentukan matriks Jacobian di titik ekuilibrium. Sifat kestabilan lokal titik ekuilibrium dapat ditentukan asalkan titik tersebut hiperbolik. Selanjutnya menentukan nilai eigen dari matriks Jacobian tersebut dengan menggunakan definisi polinomial karakteristik suatu matriks.

Salah satu alternatif menentukan nilai eigen dari polinomial karakteristik suatu matriks digunakan juga Teorema Routh- 
Hurwitz. Analisis kestabilan Routh-Hurwitz dilakukan dengan cara melihat tanda pada akar-akar polinomial karakteristik dengan matriks Jacobian yang dievaluasi pada titik kesetimbangan.

Konsep fungsi yang diferensiabel kontinu pada suatu domain, mendasari semua pembahasan dalam tulisan ini. Oleh karena itu, konsep tersebut dipaparkan paling awal. Berikut ini diberikan definisi suatu fungsi diferensiabel di suatu titik.

\section{Definisi 1}

Diberikan fungsi $f: R^{n} \rightarrow R^{n}$, dengan $f=\left(f_{1}, f_{2}, \ldots, f_{n}\right)^{T} \in R^{n}$.

Fungsi

$f$ dikatakan diferensiabel di $x_{0} \in R^{n}$ jika terdapat transformasi linear $D f\left(x_{0}\right) \in L\left(R^{n}\right)$ dengan $L\left(R^{n}\right)$ menyatakan himpunan semua operator linear pada $R^{n}$ sehingga

$$
\lim _{h \rightarrow 0} \frac{\left\|f\left(x_{0}+h\right)-f\left(x_{0}\right)-D f\left(x_{0}\right) h\right\|}{\|h\|}=0 .
$$

$D f\left(x_{0}\right)$ disebut turunan $f$ di $x_{0}$ dan $h \in R^{n}$.

Jika suatu fungsi diketahui diferensiabel maka turunan parsialnya selalu ada. Berikut secara formal diberikan teoremanya.

\section{Teorema 1}

Diberikan $f_{i}: E \subset R^{n} \rightarrow R, \quad i=1,2, \ldots, n$, dan $f: E \subset R^{n} \rightarrow R^{n}, \quad$ dengan $f=\left(f_{1}, f_{2}, \ldots, f_{n}\right)^{T} \in E$ dan $E$ himpunan terbuka. Jika fungsi $f$ diferensiabel di $x_{0} \in E$, maka $\frac{\partial f_{i}}{\partial x_{j}}, i, j=1,2, \ldots, n$ ada di $x_{0}$ dan untuk setiap $x_{0} \in E$ berakibat $D f\left(x_{0}\right) x=\sum_{j=1}^{n} \frac{\partial f\left(x_{0}\right)}{\partial x_{j}} x_{j}, \quad$ dengan $\frac{\partial f}{\partial x_{j}}=\left[\frac{\partial f_{1}}{\partial x_{j}}, \frac{\partial f_{2}}{\partial x_{j}}, \ldots, \frac{\partial f_{n}}{\partial x_{j}}\right]^{T}$.

\section{Teorema 2}

Diberikan $f: E \subseteq \mathbb{R}^{n} \rightarrow \mathbb{R}^{n}$, E himpunan terbuka. Fungsi $f$ dikatakan diferensiabel kontinu pada $E$ jika dan hanya jika $\frac{\partial f}{\partial x_{j}}$, $j=1,2, \ldots, n$ ada dan kontinu pada $E$.

\section{Sistem Persamaan Diferensial}

Diberikan sistem persamaan diferensial :

$\dot{x}_{1}=f_{1}\left(x_{1}, x_{2}, \ldots, x_{n}\right)$

$\dot{x}_{2}=f_{2}\left(x_{1}, x_{2}, \ldots, x_{n}\right)$

$\vdots$

$\dot{x}_{n}=f_{n}\left(x_{1}, x_{2}, \ldots, x_{n}\right)$,

dengan $f_{i}: E \subset R^{n} \rightarrow R, i=1,2, \ldots, n$, dan $\left(x_{1}, x_{2}, \ldots, x_{n}\right) \in E \subset R^{n}$.

Kemudian diberikan kondisi awal Sistem (2.1) yaitu $x_{i}\left(t_{0}\right)=x_{i 0}, i=1,2, \ldots, n$. Sistem (2.1) dapat ditulis sebagai

$\dot{x}=f(x)$

dengan $\quad x=\left(x_{1}, x_{2}, \ldots, x_{n}\right) \in E \subset R^{n}$, $f=\left(f_{1}, f_{2}, \ldots, f_{n}\right)^{T} \in R^{n}$ dan kondisi awal $x\left(t_{0}\right)=x_{0}=\left(x_{10}, x_{20}, \ldots, x_{n 0}\right) \in E$.

Selanjutnya, notasi $\quad x(t)=x\left(x_{0}, t\right)$ merupakan solusi Sistem (2.2) yang dimulai dari $x_{0}$.

Berikut diberikan definisi dan teorema yang menunjukkan eksistensi dan ketunggalan solusi Sistem (2.2).

\section{Definisi 2}

Diberikan $E \subset R^{n}$, dengan Ehimpunan terbuka dan $f_{i} \in C^{\prime}(E), \quad i=1,2, \ldots, n$. Vektor $x(t)$ disebut solusi Sistem (2.2) pada interval I jika $x(t)$ diferensiabel pada I dan $\dot{x}=f(x(t))$ untuk setiap $t \in I$, $x(t) \in E$.

\section{Teorema 3}

Jika $E \subset \mathbb{R}^{n}{ }^{n} E$ terbuka, $f_{i} \in C^{\prime}(E, \mathbb{R}), i=1,2, \ldots, n \quad$ dan $\quad x_{0} \in E$ maka terdapat $a>0$ sehingga masalah nilai awal $\dot{x}=f(x)$ dengan 
$x(0)=x_{0}$ mempunyai penyelesaian tunggal $x(t)$ pada interval $[-a, a]$.

Berikut didefinisikan titik ekuilibrium Sistem (2.2) dan kestabilan titik ekuilibrium Sistem (2.2).

\section{Definisi 3}

Titik $\bar{x} \in \mathbb{R}^{n}$ disebut titik ekuilibrium Sistem (2.2) jika $f(\bar{x})=0$.

\section{Definisi 4}

Titik ekuilibrium $\quad \bar{x} \in \mathbb{R}^{n}$ Sistem (2.2) dikatakan

a. Stabil jika untuk setiap $\varepsilon>0$ terdapat $\delta>0$ sedemikian sehingga untuk setiap solusi $x(t)$ Sistem (2.2) yang memenuhi

$\left\|x\left(t_{0}\right)-\bar{x}\right\|<\delta \quad$ berakibat $\|x(t)-\bar{x}\|<\varepsilon$ untuk setiap $t \geq t_{0}$.

b. Stabil asimtotik lokal jika titik ekuilibrium $\bar{x} \in \mathbb{R}^{n}$ stabil dan terdapat bilangan $\delta_{0}>0$ sedemikian sehingga untuk setiap solusi $x(t)$ yang memenuhi $\left\|x\left(t_{0}\right)-\bar{x}\right\|<\delta_{0} \quad$ berakibat $\lim _{t \rightarrow \infty} x(t)=\bar{x}$.

c. Tidak stabil jika titik ekuilibrium $\bar{x} \in \mathbb{R}^{n}$ tidak memenuhi (a).

\section{Definisi 5}

Titik ekuilibrium $\hat{x} \in R^{n}$ pada Sistem (2.2) dikatakan stabil asimtotik global jika untuk sebarang nilai awal $x\left(t_{0}\right)$ yang diberikan, setiap solusi Sistem (2.2) yaitu $x(t)$ dengan $t \rightarrow \infty$ menuju titik ekuilibrium $\hat{x}$.

\section{Kestabilan Titik Ekuilibrium Sistem Persamaan Diferensial}

Berikut ini diberikan sistem persamaan diferensial linear

$$
\begin{aligned}
& \dot{x}_{1}=a_{11} x_{1}+a_{12} x_{2}+\ldots+a_{1 n} x_{n} \\
& \dot{x}_{2}=a_{21} x_{1}+a_{22} x_{2}+\ldots+a_{2 n} x_{n} \\
& \quad \vdots \\
& \dot{x}_{n}=a_{n 1} x_{1}+a_{n 2} x_{2}+\ldots+a_{n n} x_{n}
\end{aligned}
$$

dengan $\left(x_{1}, x_{2}, \ldots, x_{n}\right) \in E \subset R^{n}$. Sistem (2.3) dapat ditulis dalam bentuk

$$
\dot{x}=A x
$$

dengan $x \in E$ dan $A$ matriks ukuran $n \times n$. Selanjutnya, diberikan sistem

$\dot{x}=f(x)$

dengan $x \in E \subset R^{n}$ dan $f: E \subset R^{n} \rightarrow R^{n}$ fungsi kontinu pada $E$.

\section{Definisi 6}

Diberikan fungsi $f=\left(f_{1}, f_{2}, \ldots, f_{n}\right)$ pada Sistem (2.4) dengan $f_{i} \in C^{\prime}(E, \mathbb{R})$, $i=1,2, \ldots, n$.

Matriks

$$
\left.\begin{array}{cccc} 
& \text { Jf }(\bar{x})= \\
\frac{\partial f_{1}}{\partial x_{1}}(\bar{x}) & \frac{\partial f_{1}}{\partial x_{2}}(\bar{x}) & \ldots & \frac{\partial f_{1}}{\partial x_{n}}(\bar{x}) \\
\frac{\partial f_{2}}{\partial x_{1}}(\bar{x}) & \frac{\partial f_{2}}{\partial x_{2}}(\bar{x}) & \ldots & \frac{\partial f_{2}}{\partial x_{n}}(\bar{x}) \\
\vdots & \vdots & & \vdots \\
\frac{\partial f_{n}}{\partial x_{1}}(\bar{x}) & \frac{\partial f_{n}}{\partial x_{2}}(\bar{x}) & \ldots & \frac{\partial f_{n}}{\partial x_{n}}(\bar{x})
\end{array}\right]
$$

dinamakan matriks Jacobian dari $f$ di titik $\bar{x}$.

\section{Definisi 7}

Diberikan matriks Jacobian If $(\bar{x})$ pada Sistem (2.5). Sistem linear $\dot{x}=J f(\bar{x}) x$ disebut linearisasi Sistem (2.4) di sekitar titik $\bar{x}$.

\section{Definisi 8}

Titik ekuilibrium $\bar{x}$ disebut titik ekuilibrium hiperbolik jika semua nilai eigen If $(\bar{x})$ mempunyai bagian real tidak nol.

\section{Definisi 9}

Vektor tak nol $x \in \mathbb{R}^{n}$ disebut vektor eigen dari $A$ jika $A x=\lambda x$, untuk suatu skalar $\lambda$. Skalar $\lambda$ disebut nilai eigen dari $A$.

\section{Definisi 10}

Polinomial karakteristik dari A didefinisikan sebagai

$$
P_{A}(\lambda)=\operatorname{det}(\lambda I-A) \text {. }
$$


Persamaan $\quad P_{A}(\lambda)=\operatorname{det}(\lambda I-A)=0$

disebut persamaan karakteristik dari matriks A.

\section{Teorema 4}

Diberikan matriks Jacobian If $(\bar{x})$ dari Sistem (2.4) dengan nilai eigen $\lambda$.

1. Jika matriks Jacobian If $(\bar{x})$ mempunyai $\quad \operatorname{Re} \lambda_{i}<0 \quad$ untuk $i=1,2, \ldots, n$, maka $\bar{x}$ dari Sistem (2.4) stabil asimtotik lokal.

2. Jika terdapat nilai eigen matriks Jacobian If $(\bar{x})$ yang mempunyai bagian real positif, maka titik ekuilibrium $\bar{x}$ dari Sistem (2.4) tak stabil.

\section{Kriteria Routh-Hurwitz}

Berdasarkan Teorema (4) bahwa untuk menguji sifat kestabilan diperlukan perhitungan untuk menentukan nilai-nilai eigen dari matriks Jacobian di titik ekuilibrium. Sebagai alternatif untuk menentukan nilai eigen tersebut digunakan Teorema Routh-Hurwitz .

\section{Teorema 5}

Jika pembuat nol pada persamaan $P(z)=a_{0} z^{n}+a_{1} z^{n-1}+\cdots+a_{n}$ (2.6) mempunyai bagian real negatif, maka $\frac{a_{1}}{a_{0}}>0, \frac{a_{n}}{a_{0}}>0, \ldots, \frac{a_{n}}{a_{0}}>0$.

Selanjutnya, tanpa mengurangi keumuman diambil $a_{0}$ positif sehingga seluruh koefisien dari Polinomial (2.6) bertanda sama, sehingga dapat dibentu

$c_{10}=a_{0}, c_{20}=a_{2}, c_{30}=a_{4}, c_{40}=$ $a_{6} c_{11}=a_{1}, c_{21}=a_{3}, c_{31}=a_{5}, c_{41}=$ $a_{7}$

Misalkan $r_{2}=\frac{a_{0}}{a_{1}}$

$c_{12}=a_{2}-r_{2} a_{3}, c_{22}=a_{4}-r_{2} a_{5}, c_{32}=a_{6}-r_{2} a_{7}, \ldots$ Misalkan $r_{j}=\frac{c_{1, j-2}}{c_{1, j-1}}$

$$
c_{i j}=c_{i+1, j-2}-r_{j} c_{i+1, j-1} \text {, }
$$

$$
c_{1 n}=c_{n} .
$$

dengan $i=1,2,3, \ldots$ dan $j=2,3,4, \ldots$

Jika $n=2 m, \quad$ maka

$c_{m+1,0}=c_{m+1,2}=a_{n}, c_{m+1,1}=$

$c_{m+1,3}=0$

Jika $\quad n=2 m-1, \quad$ maka

$c_{m 0}=a_{n-1}, c_{m 1}=a_{n}, c_{m 2}=c_{m 3}=$

0

\section{HASIL DAN PEMBAHASAN}

Model SEIR diterapkan pada penyakit yang memiliki masa inkubasi cukup lama. Pada umumnya selama masa laten tersebut individu tidak bisa menularkan penyakit, tetapi pada beberapa penyakit seperti malaria, individu yang berada dalam masa laten, infeksi dan sembuh mempunyai kemungkinan untuk menularkan penyakit.

Pada pemodelan yang akan dibentuk, digunakan asumsi-asumsi sebagai berikut :

a. Populasi terbuka

b. Individu yang berada dalam kelas laten, infeksi dan sembuh mempunyai kemungkinan untuk menularkan penyakit

c. Penyakit menyebabkan kematian (fatal)

d. Masa inkubasi cukup lama.

Definisi dari parameter - parameter yang digunakan pada model adalah

$A$ menyatakan konstanta rekruitmen dari $S$

$\beta_{10}$ menyatakan laju dari kontak efektif pada periode laten

$\beta_{20}$ menyatakan laju dari kontak efektif pada periode infeksi

$\beta_{30}$ menyatakan laju dari kontak efektif pada periode sembuh

$\mu$ menyatakan laju kematian alami

$\alpha_{10}$ menyatakan laju kematian karena penyakit pada kelas $E$

$\alpha_{20}$ menyatakan laju kematian karena penyakit pada kelas $I$

$\gamma_{0}$ menyatakan laju dari kelas $E$ ke kelas $I$

$k_{0}$ menyatakan laju kesembuhan. 
Formulasi modelnya adalah :

$\frac{d S}{d t}=A-\beta_{10} S E-\beta_{20} S I-\beta_{30} S R-\mu S$

$\frac{d E}{d t}=\beta_{10} S E+\beta_{20} S I+\beta_{30} S R-\gamma_{0} E-$

$\left(\mu+\alpha_{10}\right) E$

$\frac{d I}{d t}=\gamma_{0} E-k_{0} I-\left(\mu+\alpha_{20}\right) I$

$\frac{d R}{d t}=k_{0} I-\mu R$.

Diberikan $N(t)$ menyatakan ukuran populasi pada saat $t$, maka

$$
N(t)=S(t)+E(t)+I(t)+R(t) .
$$

Berdasarkan Sistem (1) s.d (4) dan Persamaan

$N(t)=S(t)+E(t)+I(t)+R(t) \quad$ maka $\frac{d N}{d t}=A-\mu N-\alpha_{10} E-\alpha_{20} I$.

kemudian pada saat individu manusia yang laten dan terinfeksi nol maka laju populasi manusia menjadi

$\frac{d N}{d t}=A-\mu N \Leftrightarrow \frac{d N}{d t}+\mu N=A$.

Misalkan $P(t)=\mu$ dan $Q(t)=A$, maka solusi umum persamaan (5) adalah

$N(t)=e^{-\int P(t) d t}\left[\int e^{\int p(t) d t} Q(t) d t+C\right]$

Jika disubstitusikan syarat awal $N(0)=N_{0}$ maka diperoleh

$$
N_{0}=\frac{A}{\mu}+C \Leftrightarrow C=N_{0}-\frac{A}{\mu},
$$

sehingga solusinya menjadi

$$
\begin{gathered}
N(t)=\frac{A}{\mu}+\left[N_{0}-\frac{A}{\mu}\right] e^{-\mu t} \\
\Leftrightarrow N(t)=N_{0} e^{-\mu t}+\frac{A}{\mu}\left(1-e^{-\mu t}\right) .
\end{gathered}
$$

Jika $t$ membesar maka $\lim _{t \rightarrow \infty} N(t)=\frac{A}{\mu}$, artinya jumlah populasi manusia akan menuju kapasitas batas $\frac{A}{\mu}$. Jika $N_{0}>\frac{A}{\mu}$ maka $N(t)$ turun monoton menuju kapasitas batas $\frac{A}{\mu}$ dan jika $N_{0}<\frac{A}{\mu}$ maka $N(t)$ naik monoton menuju kapasitas batas $\frac{A}{\mu}$. Untuk menyederhanakan Sistem (1) s.d (4) dimisalkan $\mu d t=d \tau$ atau $\tau=\mu t$, maka Sistem (1) s.d (4) menjadi

$$
\frac{d S}{d \tau}=\frac{A}{\mu}-\beta_{1} S E-\beta_{2} S I-\beta_{3} S R-S
$$$$
\frac{d E}{d \tau}=\beta_{1} S E+\beta_{2} S I+\beta_{3} S R-
$$

$\left(1+\gamma+\alpha_{1}\right) E$

$\frac{d I}{d \tau}=\gamma E-\left(1+k+\alpha_{2}\right) I$

$\frac{d R}{d \tau}=k I-R$

dengan

$\beta_{1}=\frac{\beta_{10}}{\mu}, \beta_{2}=\frac{\beta_{20}}{\mu}, \beta_{3}=\frac{\beta_{g 0}}{\mu}, \gamma=$

$\frac{\gamma_{0}}{\mu}, \alpha_{1}=\frac{\alpha_{10}}{\mu}, \alpha_{2}=\frac{\alpha_{20}}{\mu}, k=\frac{k_{00}}{\mu}, \delta=$

$1+\gamma+\alpha_{1}$

dan $\omega=1+k+\alpha_{2}$.

\section{Titik Ekuilibrium}

Titik ekuilibrium Sistem (5) s.d (8) diperoleh dengan menjadikan ruas kanan masing-masing persamaan sama dengan nol, yaitu

$\frac{A}{\mu}-\beta_{1} S E-\beta_{2} S I-\beta_{a} S R-S=0$,

$\beta_{1} S E+\beta_{2} S I+\beta_{3} S R-\delta E=0$,

$\gamma E-\omega I=0$

$k I-R=0$

Jika $I=0$, maka dari Persamaan (11) diperoleh $\gamma E=\Leftrightarrow E=0$.

Dari Persamaan (12) diperoleh $R=0$, dan dari Persamaan (9) diperoleh

$$
\frac{A}{\mu}-S=0 \Leftrightarrow S=\frac{A}{\mu} .
$$

Jadi diperoleh titik ekuilibrium bebas penyakit $P_{0}(S, E, I, R)=\left(\frac{A}{\mu}, 0,0,0\right)$.

Kestabilan Titik Ekuilibrium Bebas Penyakit

\section{Teorema 1}

Misalkan $R_{0}=\frac{A\left(\beta_{1} \omega+\beta_{2} \gamma+\beta_{\mathrm{g}} k \gamma\right)}{\delta \omega \mu}$.

Jika $R_{0} \leq 1$ maka Sistem (5) s.d (8) mempunyai satu titik ekuilibrium bebas penyakit yaitu $P_{0}(S, E, I, R)=\left(\frac{A}{\mu}, 0,0,0\right)$. 


\section{Teorema 2}

Misalkan $\quad R_{0}=\frac{A\left(\beta_{1} \omega+\beta_{2} \gamma+\beta_{\mathrm{g}} k \gamma\right)}{\delta \omega \mu}$. Jika $R_{0}<1$, maka titik ekuilibrium bebas penyakit $P_{0}\left(\frac{A}{\mu}, 0,0,0\right)$ pada Sistem (5) s.d (8) adalah stabil asimtotik lokal.

\section{Bukti}

Matriks Jacobian di titik ekuilibrium $P_{0}\left(\frac{A}{\mu}, 0,0,0\right)$ adalah

$$
\begin{gathered}
I f\left(P_{0}\right)=J\left(f\left(\frac{A}{\mu}, 0,0,0\right)\right) \\
=\left[\begin{array}{cccc}
-1 & \frac{-\beta_{1} A}{\mu} & \frac{-\beta_{2} A}{\mu} & \frac{-\beta_{3} A}{\mu} \\
0 & \frac{\beta_{1} A}{\mu}-\delta & \frac{\beta_{2} A}{\mu} & \frac{\beta_{8} A}{\mu} \\
0 & \gamma & -\omega & 0 \\
0 & 0 & k & -1
\end{array}\right] .
\end{gathered}
$$

Polinomial karakteristik If $\left(P_{0}\right)$ adalah

$$
P(\lambda)=\operatorname{det}\left(\lambda I-J f\left(P_{0}\right)\right)=\left|\lambda I-J f\left(P_{0}\right)\right| .
$$

Persamaan karakteristiknya adalah

$$
\left|\lambda I-J f\left(P_{0}\right)\right|=0
$$

$$
\begin{aligned}
& \Leftrightarrow \\
& {\left[\begin{array}{llll}
\lambda & 0 & 0 & 0 \\
0 & \lambda & 0 & 0 \\
0 & 0 & \lambda & 0 \\
0 & 0 & 0 & \lambda
\end{array}\right]-} \\
& {\left[\begin{array}{cccc}
-1 & \frac{-\beta_{1} A}{\mu} & \frac{-\beta_{2} A}{\mu} & \frac{-\beta_{g} A}{\mu} \\
0 & \frac{\beta_{1} A}{\mu}-\delta & \frac{\beta_{2} A}{\mu} & \frac{\beta_{g} A}{\mu} \\
0 & \gamma & -\omega & 0 \\
0 & 0 & k & -1
\end{array}\right] \mid=0} \\
& \Leftrightarrow(\lambda+1)\left[\lambda^{a}+\left(1+\delta+\omega-\frac{\beta_{1} A}{\mu}\right) \lambda^{2}+\right. \\
& \left(\delta+\delta \omega+\omega-\frac{\beta_{1} A}{\mu}-\frac{\beta_{1} A \omega}{\mu}-\frac{\beta_{2} A Y}{\mu}\right) \lambda+ \\
& \left.\left.\frac{\left(\delta \omega-\frac{\beta_{1} A \omega}{\mu}-\frac{\beta_{2} A Y}{\mu}-\right.}{\mu}\right)\right]=0 .
\end{aligned}
$$

Persamaan (13) dapat ditulis menjadi $(\lambda+1)\left(\lambda^{3}+A \lambda^{2}+B \lambda+C\right)=0$ (14) dengan

$$
A=1+\delta+\omega-\frac{\beta_{1} A}{\mu}
$$

$$
\begin{gathered}
B=\delta+\delta \omega+\omega-\frac{\beta_{1} A}{\mu}-\frac{\beta_{1} A \omega}{\mu}-\frac{\beta_{2} A Y}{\mu} \\
C=\delta \omega-\frac{\beta_{1} A \omega}{\mu}-\frac{\beta_{2} A Y}{\mu}-\frac{\beta_{8} A \gamma k}{\mu} .
\end{gathered}
$$

Salah satu nilai eigen dari persamaan (14) adalah -1 , nilai-nilai eigen yang lain merupakan akar-akar dari polinomial berikut

$Q(\lambda)=\lambda^{3}+A \lambda^{2}+B \lambda+C$.

Perhatikan bahwa

$$
A=1+\delta+\omega-\frac{\beta_{1} A}{\mu} .
$$

Karena $R_{0}=\frac{A\left(\beta_{1} \omega+\beta_{2} \gamma+\beta_{\mathrm{g}} k \gamma\right)}{\delta \omega \mu}<1$, maka

$$
\begin{gathered}
A\left(\beta_{1} \omega+\beta_{2} \gamma+\beta_{3} k \gamma\right)<\delta \omega \mu \\
\Leftrightarrow \beta_{1} A \omega+\beta_{2} A \gamma+\beta_{3} A k \gamma<\delta \omega \mu \\
\Leftrightarrow \frac{\beta_{1} A \omega}{\omega \mu}+\frac{\beta_{2} A \gamma}{\omega \mu}+\frac{\beta_{3} A k \gamma}{\omega \mu}<\delta
\end{gathered}
$$

$$
\begin{gathered}
\Leftrightarrow \frac{\beta_{1} A}{\mu}+\frac{\beta_{2} A Y}{\omega \mu}+\frac{\beta_{\mathrm{g}} A k \gamma}{\omega \mu}<\delta \\
\Leftrightarrow \frac{\beta_{1} A}{\mu}<\delta .
\end{gathered}
$$

Jadi $A=1+\delta+\omega-\frac{\beta_{1} A}{\mu}>0$.

Selanjutnya

$$
\begin{aligned}
& B=\delta+\delta \omega+\omega-\frac{\beta_{1} A}{\mu}-\frac{\beta_{1} A \omega}{\mu}-\frac{\beta_{2} A Y}{\mu} \\
= & \delta+\delta \omega+\omega-\left(\frac{\beta_{1} A}{\mu}+\frac{\beta_{1} A \omega}{\mu}+\frac{\beta_{2} A Y}{\mu}\right) \\
= & \left(\delta-\frac{\beta_{1} A}{\mu}\right)+\left(\delta \omega-\frac{\beta_{2} A Y}{\mu}\right)+ \\
& \left(\omega-\frac{\beta_{1} A \omega}{\mu}\right) .
\end{aligned}
$$

Dari (17) diketahui bahwa $\left(\delta-\frac{\beta_{1} A}{\mu}\right)>0$, dan dari (16) diketahui bahwa

$$
\begin{aligned}
& \frac{\beta_{1} A}{\mu}+\frac{\beta_{2} A Y}{\omega \mu}+\frac{\beta_{\mathrm{g}} A k \gamma}{\omega \mu}<\delta \\
& \Leftrightarrow \frac{\beta_{\mathrm{z}} A Y}{\omega \mu}<\delta \Leftrightarrow \frac{\beta_{\mathrm{z}} A Y}{\mu}<\delta \omega \\
& \Leftrightarrow \delta \omega-\frac{\beta_{\mathrm{z}} A Y}{\mu}>0 .
\end{aligned}
$$

Perhatikan bahwa

$$
\left(\omega-\frac{\beta_{1} A \omega}{\mu}\right)=\left(1-\frac{\beta_{1} A}{\mu}\right) \omega .
$$

Dari (16) diketahui

$$
\begin{aligned}
& \frac{\beta_{1} A}{\mu}+\frac{\beta_{2} A y}{\omega \mu}+\frac{\beta_{\mathrm{g}} A k y}{\omega \mu}<\delta \\
& \Leftrightarrow \frac{\beta_{1} A}{\mu}<\delta=1+\gamma+\alpha_{1},
\end{aligned}
$$


akibatnya $\quad\left(1-\frac{\beta_{1} A}{\mu}\right)>0, \quad$ sehingga $\left(\omega-\frac{\beta_{1} A \omega}{\mu}\right)=\left(1-\frac{\beta_{1} A}{\mu}\right) \omega>0$.

Jadi

$$
\begin{aligned}
& B=\left(\delta-\frac{\beta_{1} A}{\mu}\right)+\left(\delta \omega-\frac{\beta_{2} A Y}{\mu}\right)+ \\
& \left(\omega-\frac{\beta_{1} A \omega}{\mu}\right)>0 .
\end{aligned}
$$

Selanjutnya

$$
\begin{gathered}
C=\delta \omega-\frac{\beta_{1} A \omega}{\mu}-\frac{\beta_{2} A \gamma}{\mu}-\frac{\beta_{g} A \gamma k}{\mu} \\
=\delta \omega-\left(\frac{\beta_{1} A \omega}{\mu}+\frac{\beta_{2} A \gamma}{\mu}+\frac{\beta_{3} A \gamma k}{\mu}\right) \\
=\delta \omega-\frac{A\left(\beta_{1} \omega+\beta_{2} \gamma+\beta_{g} k \gamma\right)}{\mu} .
\end{gathered}
$$

Karena $R_{0}=\frac{A\left(\beta_{1} \omega+\beta_{2} \gamma+\beta_{g} k \gamma\right)}{\delta \omega \mu}<1$, maka

$$
\begin{gathered}
A\left(\beta_{1} \omega+\beta_{2} \gamma+\beta_{3} k \gamma\right)<\delta \omega \mu \\
\Leftrightarrow \frac{A\left(\beta_{1} \omega+\beta_{2} \gamma+\beta_{g} k \gamma\right)}{\mu}<\delta \omega .
\end{gathered}
$$

Jadi $\quad C=\delta \omega-\frac{A\left(\beta_{1} \omega+\beta_{2} \gamma+\beta_{8} k \gamma\right)}{\mu}>0$.

Selanjutnya akan ditunjukkan $A B>C$.

Karena $A=1+\delta+\omega-\frac{\beta_{1} A}{\mu} \quad$ dan $\left(\delta-\frac{\beta_{1} A}{\mu}\right)>0$ maka jelas $A>1$.

Selanjutnya karena $A>1, B>0$ dan $C>0$ maka $A B>B$, jadi cukup ditunjukkan bahwa $B>C$.

Perhatikan bahwa

$$
\begin{aligned}
& B=\delta+\delta \omega+\omega-\frac{\beta_{1} A}{\mu}-\frac{\beta_{1} A \omega}{\mu}-\frac{\beta_{2} A Y}{\mu} \\
= & \left(\delta-\frac{\beta_{1} A}{\mu}\right)+\omega+\delta \omega- \\
\left(\frac{\beta_{1} A \omega}{\mu}+\frac{\beta_{2} A Y}{\mu}\right) & \\
& >\delta \omega-\left(\frac{\beta_{1} A \omega}{\mu}+\frac{\beta_{2} A Y}{\mu}\right) \\
> & \delta \omega-\left(\frac{\beta_{1} A \omega}{\mu}+\frac{\beta_{2} A Y}{\mu}+\frac{\beta_{2} A Y k}{\mu}\right)=C .
\end{aligned}
$$

Dari Persamaan (18), (19), (20) dan (21) diperoleh bahwa

$$
A>0, B>0, C>0 \text { dan }>C \text {. }
$$

Berdasarkan nilai koefisien polinomial $Q(\lambda)$ pada Persamaan (15) diperoleh

$a_{0}=1, a_{1}=A, a_{2}=B$

$$
a_{3}=C, a_{4}=0, a_{5}=0 .
$$

Dari nilai diatas, dapat dibentuk matriks Hurwitz sebagai berikut

$$
H=\left[\begin{array}{lll}
a_{1} & a_{0} & 0 \\
a_{3} & a_{2} & a_{1} \\
a_{5} & a_{4} & a_{3}
\end{array}\right]=\left[\begin{array}{ccc}
A & 1 & 0 \\
C & B & A \\
0 & 0 & C
\end{array}\right] .
$$

Berdasarkan matriks Hurwitz diatas dapat ditentukan determinan Hurwitz yaitu

$$
\Delta_{1}=a_{1}=A
$$

$\Delta_{2}=\left|\begin{array}{ll}a_{1} & a_{0} \\ a_{3} & a_{2}\end{array}\right|=\left|\begin{array}{ll}A & 1 \\ C & B\end{array}\right|=A B-C$

$\Delta_{3}=\left|\begin{array}{lll}A & 1 & 0 \\ C & B & A \\ 0 & 0 & C\end{array}\right|=A B C-C^{2}=$

$(A B-C) C$

Berdasarkan nilai $A, B$ dan $C$, maka dapat ditentukan bahwa

1. Karena nilai $A>0$ maka $\Delta_{1}=A>0$

2. Karena nilai $A>0, B>0, C>0$ dan $A B>C$, maka

$$
\Delta_{2}=A B-C>0
$$

3. Karena nilai $A>0, B>0, C>0$ dan $A B>C$, maka

$$
\Delta_{3}=(A B-C) C>0 \text {. }
$$

Karena nilai $\Delta_{1}>0, \Delta_{2}>0$ dan $\Delta_{3}>0$, maka polinomial $\mathrm{Q}(\lambda)$ mempunyai pembuat nol yang bagian realnya negatif. Hal ini berakibat semua bagian real nilai eigen pada matriks $I f\left(P_{0}\right)$ bernilai negatif untuk $R_{0}<1$. Jadi titik ekuilibrium $P_{0}\left(\frac{A}{\mu}, 0,0,0\right)$ stabil asimtotik lokal.

\section{SIMPULAN}

Model matematika epidemi SEIR dengan adanya kemampuan infeksi pada periode laten, infeksi dan sembuh adalah $\frac{d S}{d t}=A-\beta_{10} S E-\beta_{20} S I-\beta_{30} S R-$ $\mu S$ 


$$
\begin{aligned}
& \frac{d E}{d t}=\beta_{10} S E+\beta_{20} S I+\beta_{30} S R- \\
& \gamma_{0} E-\left(\mu+\alpha_{10}\right) E \\
& \frac{d I}{d t}=\gamma_{0} E-k_{0} I-\left(\mu+\alpha_{20}\right) I \\
& \frac{d R}{d t}=k_{0} I-\mu R .
\end{aligned}
$$

Jika $R_{0}<1$ maka model (1) mempunyai satu titik ekuilibrium bebas penyakit $P_{0}\left(\frac{A}{\mu}, 0,0,0\right)$. Titik ini menyatakan bahwa semua individu dalam keadaan sehat. Jika $R_{0}<1$ maka titik ekuilibrium $P_{0}\left(\frac{A}{\mu}, 0,0,0\right)$ stabil asimtotik lokal, ini menunjukkan bahwa dalam jangka waktu yang panjang individu yang ada dalam populasi menuju titik $P_{0}\left(\frac{A}{\mu}, 0,0,0\right)$ atau tidak terdapat individu yang terjangkit penyakit.

\section{SARAN}

Karena berbagai keterbatasan, penulis menyadari penelitian dan tulisan ini masih banyak kekurangannya. Banyak hal yang belum tercakup dalam penelitan ini. Perlu dikaji lebih lanjut kestabilan global titik ekuilibrium endemik atau generalisasinya untuk masalah model epidemi lainnya atau pada bidang ilmu lainnya.

\section{DAFTAR PUSTAKA}

Anton H, dan Rorres,C.,2004. Aljabar Linear Elementer Versi Aplikasi, Edisi Kedelapan, alih bahasa oleh Indriasari,R dan Harmaen,I., Erlangga, Jakarta.

Arrowsmith, D.R. dan Place, C.M., 1992, Dynamical System Differential Equation, Maps and Chaotic Behaviour, Chapman \& Hall Mathematic, London.

Capazzo, V., Mathematical Structures of Epidemic Systems, Springer-Verlag, Heidelberg, 2008.
Gantmacher, F.R., 1959, The Theory of Matrices, Chelsea Publishing Company, New York

Hanh, Wolfgang, 1967, Stability of Motion, Springer - Verlag, New York.

Hirsch, M.W., dan Smith, Monotone Dynamical Systems, University of California, Berkeley, 2004.

Luenberger, G.D., 1979, Introduction to Dynamic System Theory, Models \& Aplication, John Wiley \& Sons, New York.

Olsder, G.J., 1994, Mathematical System Theory, Delftse Uitgevers Maatschappij, Netherlands.

Perko L., 1991, Differential Equations and Dynamical Systems, Springer-Verlag, New York.

Verhultz, Ferdinand, 1990, Nonlinear Differential Equations and Dynamical Systems, Springer-Verlag,Berlin.

Wiggins S, 1990, Introduction to Applied Nonlinear Dynamical Systems and Chaos, Springer-Verlag, New York. 